\title{
SYSTEMATIC MAPPING STUDY 2012-2017: QUALITY AND EFFECTIVENESS MEASUREMENT IN MOOC
}

\author{
Rocio QUILIANO-TERREROS \\ ORCID: https://orcid.org/0000-0003-0595-4615 \\ Department of Research, Universidad Privada del Norte \\ Lima, Peru \\ Darinka RAMIREZ-HERNANDEZ \\ ORCID: https://orcid.org/0000-0003-4789-6433 \\ School of Humanities and Education, Tecnologico de Monterrey \\ Monterrey, Mexico \\ Pablo BARNIOL \\ ORCID: https://orcid.org/0000-0002-4817-0215 \\ School of Humanities and Education, Tecnologico de Monterrey \\ Monterrey, Mexico
}

Received Date: 25/03/2018 Accepted Date: 05/09/2018

\begin{abstract}
Massive Open Online Courses (MOOCs) concentrate an important number of students and are set up as an alternative for acquiring knowledge and continuing education. The objective of this article is to analyze how the quality and effectiveness of the MOOCs were measured in empirical studies between 2012 and 2017. For which a systematic mapping study of articles was performed by using databases of Scopus and Web of Science. These articles were analyzed according to the: (1) context of the publication, (2) type of developing institutions and distribution platforms of the MOOC, and (3) characteristics of the empirical studies. It was identified that $54 \%$ of the developing institutions were universities and that $31 \%$ of the platforms that distributed the MOOC are of Coursera. These articles were also analyzed by type of study, the more frequently used indicators to measure the effectiveness, and the more frequently used focus points (approaches) to measure quality. The results of this study are useful because it allows having a general view of the most frequently utilized methodologies to measure quality and effectiveness in MOOCs.
\end{abstract}

Keywords: Systematic Mapping Study, Massive Open Online Courses, MOOCs, quality, effectiveness, measurement.

\section{INTRODUCTION}

Massive Open Online Courses (MOOCs) are an educational innovation both in technology and in didactic strategies. These new forms of delivering massive, open, and, distance education within reach of any human, in whatever place they are at, and most importantly, free of charge, also require measuring their quality and effectiveness. Analyzing the previous literature on MOOCs, it was found that this line of research needed a study that synthesized how quality and effectiveness have been measured in these courses (more details in the previous literature section below). For such reason, this article had the objective of identifying how quality and effectiveness were measured in the MOOCs between the years 2012-2017. The results of this study are useful because they provide a general view of the most frequently utilized methods to measure quality and effectiveness in MOOCs. 
The Massive Open Online Courses (MOOCs) have become an important teaching and learning alternative which is reflected by its fast growth (Ruiz Bras, 2016). The latter can be demonstrated in the coverage of some platforms like Coursera (2017), which stated, that by 2016, it had at least 18 million students in different parts of the world and that also some countries informed a $70 \%$ or above growth in these platforms. On the other hand, UNESCO (2017) published the document: "Making sense of MOOCs; A Guide for Policy-Makers in Developing Countries", where it recognizes the great potential of MOOCs and promotes their development as a strategy in the frame of the plan "Education 2030: Quality and Inclusive Education". Likewise, Isaksson, Garvare, Johnson, Kuttainen, and Pareigis (2015) inform them as an alternative to a growing and unsatisfied demand of continuous education, despite their lack of acknowledgment to the official value of most of these (Law, 2015).

Having this overview in mind, an important increase of investigations about MOOCs is observed, which encompass different aspects and note different challenges as an effort to search parameters, methodologies, and procedures that allow them to be an alternative that contributes towards formal education. The latter can be demonstrated in the Scopus database, where a constant increase of the studies about MOOCs and their connections with quality, effectiveness, and measurements are observed. In Table 1 it is seen that from the year 2012 to November 2017, 2010 articles have been published. From 2009 to 2017, a tendency towards an increase in publications on this subject is observed (see first line of the table), where from the total, since $2009,28 \%$ are articles referring to either quality, effectiveness, achievement and/or success (see the second line of the table) and $24 \%$ to measurement and/or evaluation (see the third line). The review of the literature is up-to-date, comprehensive and addresses the need for the manuscript.

Table 1. All the publications about MOOCs, quality, effectiveness and measurement in SCOPUS (January 2009-November 2017)

\begin{tabular}{|c|c|c|c|c|c|c|c|c|c|c|c|}
\hline Search & 2009 & 2010 & 2011 & 2012 & 2013 & 2014 & 2015 & 2016 & 2017 & Total & $\%$ \\
\hline $\begin{array}{l}\text { Massive Open } \\
\text { Online Course* } \\
\text { (Massive Open } \\
\text { Online Course*) }\end{array}$ & 2 & 0 & 9 & 12 & 169 & 362 & 485 & 506 & 476 & 2021 & 100 \\
\hline $\begin{array}{l}\text { AND (quality } \\
\text { OR effectiveness } \\
\text { OR achievement } \\
\text { OR success) } \\
\text { (Massive Open } \\
\text { Online Course*) }\end{array}$ & 1 & 0 & 1 & 2 & 39 & 101 & 134 & 138 & 151 & 567 & 28 \\
\hline $\begin{array}{l}\text { AND (measure } \\
\text { or assessment } \\
\text { OR evaluation } \\
\text { OR appraisal) }\end{array}$ & 0 & 0 & 2 & 2 & 32 & 84 & 117 & 126 & 123 & 486 & 24 \\
\hline
\end{tabular}

Note. Source: Build with SCOPUS data. Until November 2017

\section{Massive Open Online Courses}

According to Patru and Balaji (2016), MOOCs are online courses designed for a massive number of participants (thousands), which can be accessed by any person with an Internet connection from any place in the world and do not require any entry requirement, meaning they are free of charge. The MOOCs are developed under the concept of Open Learning or Open Education, where it is expected to resume the academic characteristic of interaction, access to debate, trading of knowledge and transparency beyond only the provision of contents, which can approach the democratization of knowledge (Cormier and Siemens, 2010). According to Baturay (2015), the fundamental characteristics of MOOCs are: 
$>$ Open. To anyone who wishes to enroll, free of charge and the products resulting from the course must also be freely available (investigations, essays, etc.).

$>$ Participative. The MOOCs' basis of learning is the participation, contribution, exchange and willing interaction from the students.

$>$ Distributed. MOOCs are based on the connectivism approach, so knowledge must be distributed in a network of participants. The course is generally carried out in social learning environments, where the participants interact with the material.

MOOCs have less than 20 years of history, these began between the years 2000-2007 within the Open Education movement. The first MOOC appeared in 2008 and was named "Connectivism and Connected Knowledge". Their originators were George Siemens and Stephen Downes and it was offered through the University of Manitoba, Canada. By 2011, Stanford University offered a course on artificial intelligence which enrolled 160000 students. In 2012 the MOOCs distribution platforms appeared: Audicitu, Coursera, MITEDX which today conglomerate thousands of courses and millions of students (El Ahrache, Hassan, Tabaa, and Medouri, 2013; Greene, Oswald, and Pomerantz, 2015). This evolution is observed graphically in Figure 1.

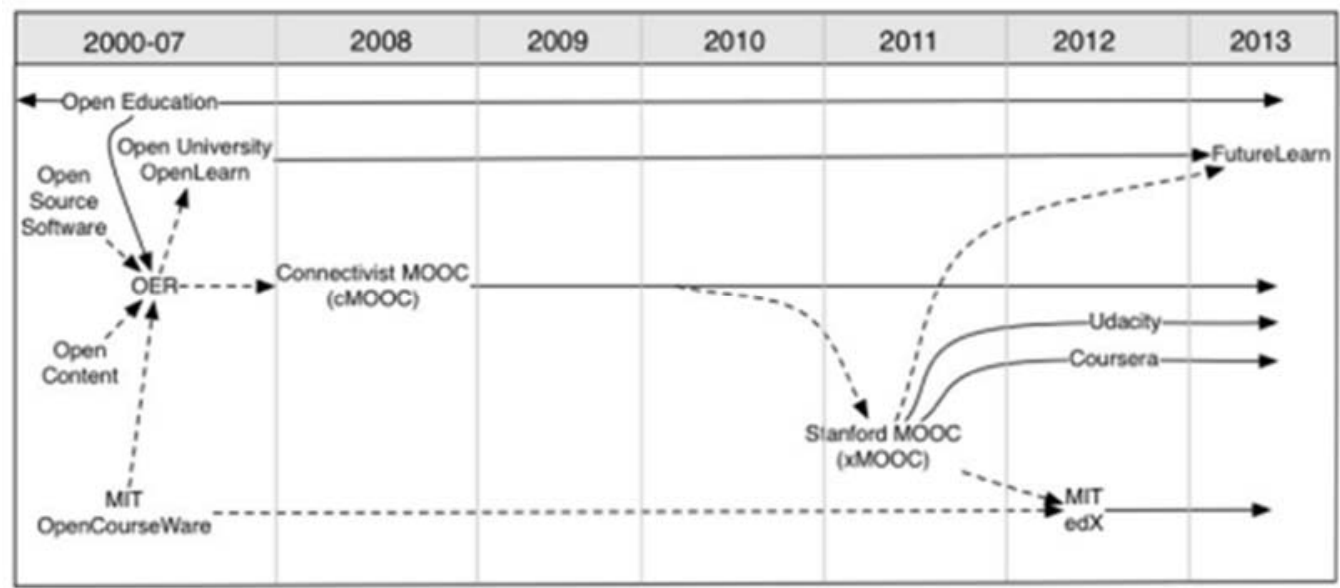

Figure 1. Timeline of MOOC evolution. Source: El Ahrache et al. (2013)

It is important to mention that the amount of reported studies in Scopus (Table 1) is coherent with the evolution of MOOCs in time (Figure 1), where it is observed that these courses were made massive in 2012 through various platforms and a year later, in 2013 the production of articles increased by $1300 \%$ (from 12 to 169 articles, first line of the table).

\section{LITERATURE REVIEW}

The previous literature reviews on MOOC began to appear in the literature since 2013. Between 2013 and 2018 ten relevant literature reviews about MOOCs were published (Liyanagunawardena et al., 2013; Yousef et al., 2014; Sa'Don et al., 2015; Chiappe-Laverde et al., 2015; Bozkurt et al., 2016; Veletsianos \& Shepherdson, 2016; Bozkurt et al., 2017; Cabero-Almenara et al., 2017; Zawacki-Richter et al., 2018; Zhu et al., 2018). The first literature reviews (Liyanagunawardena et al., 2013; Yousef et al., 2014; Sa'Don et al., 2015) identified the most researched topics. For example, Sa'Don, Alias, \& Ohshima (2015) reviewed the research trends of higher education MOOCs in 164 articles between the years 2008-2014; they identified that the ten most studied topics in order of importance were: Pedagogy, Evaluation and Accreditation, Commitment or Motivation, Knowledge Exchange, Cultural Diversity, Technology, Social Interaction, Retention of participants, Learning Analytics, and Policy and instructional design. 
Between 2016 and 2018, three literature review works are relevant (Bozkurt et al., 2016; Bozkurt et al., 2017; Zawacki-Richter et al., 2018). Given the importance of these studies, a summary of the main results of the two latter studies follows. Bozkurt et al. (2017) conducted an important review of 362 empirical articles from 2008 to 2015. The authors identified three main research areas: theories and models (27\%), learner characteristics (15.7\%), and instructional design (11\%). Additionally, they found that: the related literature is dominated by research on xMOOCs, the discourse in MOOC articles takes a mostly neutral standpoint, and theoretical or conceptual studies are preferred by researchers. Zhu et al. (2018) studied the research paradigms and topics of MOOCs analyzing 146 empirical studies from 2014 to 2016. The authors found five main results: most studies used quantitative research methods, the most frequently adopted data collection method was the survey, more than half of the collected studies used at least two data collection methods, the majority of researchers used descriptive statistics to analyze data, and the research focus was mainly on students. The current state of art summarized above shows different important issues about MOOCs. However, the present article will be focused only on the effectiveness and quality measurement of MOOCs; this will be shown below.

\section{The Quality of Massive Open Online Courses}

The quality in education is a complex topic to address. For Wittek and Kvernbekk (2011), there is no accurate definition of quality in education since it can change under the perspective of the educator, student, authority, employer or parent. On the other hand, and after reviewing scientific literature, it is seen that quality must be understood by the level of education being either early, basic or higher education. For these reasons, and considering the purpose of this article, the parameters of quality of MOOCs in various theoretical studies are presented.

Patru and Balaji (2016) propose to frame the quality of MOOCs from the most general approach to quality, where two factors are met: 1. A profound understanding of the expectations and needs of the users, and 2 . That the MOOC adapts to or satisfies these aspects. For the abovementioned, they propose two reference parameters: 1. The E-xcellence Framework, which verifies the strategy of the management, design of the curriculum, design of the course, delivery form, support staff for the resources and support for the student and 2. OpenupEd Quality Label (which results from the first parameter) and which verifies aspects at an institutional level (with the same evaluation criteria of the E-xcellence Framework) and also, from the course. The latter combines diverse criteria such as clarity of the learning results, coherence between the results and the contents, learning strategies, relevance and pertinence among other aspects.

In scientific empirical and theoretical literature, three parameters of quality evaluation of MOOCs are observed, which are adaptations of evaluations of online courses. These are:

$>$ Arias Masa Proposal (2007): The author proposes the evaluation of quality of virtual courses by means of the following dimensions, each with its own indicators: pedagogical quality (10 indicators), technical quality ( 4 indicators), management (3 indicators), usability ( 3 indicators) and general assessment ( 2 indicators). This proposal has been adapted for some empirical studies such as those of Mengual-Andrés, Lloret Catala, and Roig Vila (2015) and Roig-Vila, Mengual Andrés and Suarez Guerrero (2014).

$>$ ADECUR Proposal by Cabero Almenara and López Meneses (2009). Its acronym means Description of a Didactic Instrument for the Analysis of Models and Teaching Strategies of Online University Courses. Here the authors propose two dimensions, each with a progression axis. The dimensions are: 1) Psycho-didactic dimension with the following axis: virtual environment, type of promoted learning, goals, contents, activities and their sequencing, the assessment, and the tutorial action; 2) Dimension of technical aspects with the axis: technical aspects and resources. This instrument was adapted for the evaluation of MOOCs in the article by Baldomero Ramírez-Fernandez, Salmerón Silvera and López Meneses (2015). 
Proposal of Quality of Virtual Education (AENOR, 2012), from the Management of Quality of the Spanish Regulation UNE 66181:2012. It proposes three levels of evaluation: acknowledgment for the employability formation, learning methodology, and accessibility. This regulation has a strong component for the analysis of the users' needs for the development of its proposal and was adapted for the study by Baldomero RamírezFernandez and Salmerón Silvera (2015).

By the end of this section is noted that the quality standards of MOOCs are still in a construction process. There are various proposals with some points in common mainly on the pedagogical design, as well as in the technical aspect and accessibility, however, there are also strong differences and scopes.

\section{Effectiveness in the Massive Open Online Courses}

According to the reviewed literature, unlike quality which requires parameters for an evaluation, the effectiveness of MOOCs is measured by various variables and indicators that can be expressed in: retention (given the high number of students' dropout), certification of completion of the course, fulfillment of achievements, change in knowledge or attitude, student's experience, among others (Adam, Young-Wolff, Konar, and Winkleby, 2015; MacKay, Langford, and Waran, 2016; Masanet, Chang, Yao, Briam, and Huang, 2014; Tiejun, 2016). It is important to mention that considering that MOOCs are not official studies, there are no formal statistics which allow having comparison parameters, beyond the results obtained in the published studies.

\section{Previous Literature Review on MOOCs' Quality and Effectiveness}

There are two previous revisions of literature about the quality and effectiveness of MOOCs: (1) The study of Gamage, Fernando and Perera (2015), and the study of Duart, Roig-Vila, Mengual-Andrés and Maseda (2017). In the first study, Gamage et al. (2015) performed a review of the quality of MOOCs with the objective of identifying quality metrics that would allow them to evaluate MOOCs between 2012-2015 and to analyze 26 articles. Their results yielded that only three empirical articles provided dimensions for the quality of a MOOC and seven articles on parameters of quality that propose to evaluate MOOCs. Finally, they mention that it is necessary to fill the significant gap in the investigation related to producing and evaluating quality MOOCs.

On the other hand, in the second study, Duart et al. (2017) made a systematic revision of literature in the JCR and Scopus databases with the objective of determining aspects relating to the pedagogical quality of MOOCs. The authors developed an analysis based on seven categories: planning of the course, contents, methodology, resources and activities, motivation, communication and evaluation, and certification. The results show that the assessments of MOOCs yielded a quality average slightly higher than the mean. Furthermore, they warn about the lack of studies directly related with the pedagogical quality of MOOCs, so that it is deemed necessary to develop further studies that, from methodological rigor, tend to obtain conclusive results.

Both revisions of previous literature coincide in underlining the little existence of empirical articles that evaluate the quality and effectiveness of MOOCs. It also must be noted that the main difference between our study and these two previous studies (Gamage et al. (2015) and Duart et al (2017) lies in the depth of our analysis and in the larger period of years considered in our study. It must also be noted that the two studies only analyze the articles until 2015 and the second study focuses solely on the theme of quality. This allows generating a knowledge basis in order to evaluate MOOCs with quality and effectiveness strategies with theoretical and empirical support. 


\section{METHODOLOGY}

Systematic reviews are, according to Gisbert and Bonfill (2004), scientific investigations with prefigured methods that synthesize the results of the original studies. For these authors, these reviews have four basic characteristics: (1) they are synthesis of information with a practical approach, (2) they are based on available scientific evidence, (3) they formulate clearly defined questions, and (4) they use systematic and explicit methods to identify and analyze the studies. These reviews can drive future research studies (i.e. Russell, 2012). One of these systematic reviews is the systematic mapping of literature (Grant \& Booth, 2009), which offers a broad review of primary studies in a specific area with the purpose of identifying the available evidence on the subject (Kitchenham and Charters, 2007).

The current systematic mapping of literature was performed following the steps established by Peterson et al. (2008), for which: only empirical articles indexed in Scopus or Web of Science were considered, the articles published between the years 2012 and 2017 and where quality, effectiveness or both as a set were evaluated or measured. Peterson et al. (2008) established five steps that guide systematic mappings: (1) Definition of research questions, (2) Conduct search for primary studies, (3) Screening of papers for inclusion and exclusion, (4) Classification scheme, and (5) Data extraction and mapping of studies. Next, we describe how each of these steps is followed in the present study.

\section{Step 1: Definition of Research Questions}

According to Petersen et al. (2008), the reviews of literature begin with the definition of the research questions. The research questions that guided this systematic review of the literature were the following:

(RQ1) Context of the publication

1. How are the publications distributed by country of publication?

2. How are the publications distributed by year of publication?

3. How are the publications distributed by the most frequent magazines of publication?

4. How are the publications distributed by country of affiliation of the first author?

(RQ2) Type of developing institutions and distributing platforms of MOOCs

1. How are the publications distributed by the type of institution that develops the MOOC?

2. How are the publications distributed by the platform that distributes the MOOC?

(RQ3) Characteristics of the empiric studies

1. How are the publications distributed by type of study?

2. How are the empirical studies distributed according to the most frequent indicators to measure effectiveness?

3. How are the empirical studies distributed according to the most frequent approaches to measure quality?

\section{Steps 2 \& 3: Conduct Search for Primary Studies and Screening of Papers for Inclusion and Exclusion}

For the search strategy, the keywords obtained from the research objective were used and their equivalents or synonyms were considered based on the Thesaurus of the UNESCO and on the articles of Duart et al. (2017) and Gamage et al. (2015). The keywords used were:

Massive Open Online Course OR MOOC* (The asterisk is used to develop a dashed search)

$>$ Quality

$>$ Effectiveness OR achievement OR success

$>$ Measure OR assessment OR evaluation OR appraisal 
The following general conditions were also considered equally for both databases: 1) The search was made in English in the boxes for title, keywords and in the case of Scopus the summary was included; and 2) Filters for type of documents and years were applied, and only "articles" and the period "2012-2017" were selected respectively. Table 2 shows the results of the search and the process of exclusion. In the results of the first search, 115 articles were found in both databases (Scopus and Web of Science): 54 about quality measurement, 52 about effectiveness measurement and 9 about both quality and effectiveness measurement.

Table 2. Strategy, search results and process of exclusion in Scopus and Wos.

\begin{tabular}{|c|c|c|c|c|c|}
\hline Search & $\begin{array}{l}\text { Number of } \\
\text { Search }\end{array}$ & Search strategy & $\begin{array}{l}\text { Articles found in } \\
\text { WOS and Scopus }\end{array}$ & $\begin{array}{l}\text { Excluded } \\
\text { Articles }\end{array}$ & $\begin{array}{c}\text { Analyzed } \\
\text { Articles }\end{array}$ \\
\hline $\begin{array}{c}\text { MOOC } \\
\text { Quality } \\
\text { Measurement }\end{array}$ & 4 & $\begin{array}{l}\text { (MOOC* OR Massive } \\
\text { open online courses) } \\
\text { AND (measure OR } \\
\text { assessment OR } \\
\text { evaluation OR appraisal) } \\
\text { AND (quality)) }\end{array}$ & 54 & 41 & 13 \\
\hline $\begin{array}{c}\text { MOOC } \\
\text { Effectiveness } \\
\text { measurement }\end{array}$ & 5 & $\begin{array}{l}\text { (MOOC* OR Massive } \\
\text { open online courses) } \\
\text { AND (measure OR } \\
\text { assessment OR } \\
\text { evaluation OR appraisal) } \\
\text { AND effectiveness OR } \\
\text { achievement OR success) }\end{array}$ & 52 & 44 & 8 \\
\hline $\begin{array}{c}\text { MOOC } \\
\text { Quality and } \\
\text { effectiveness } \\
\text { measurement }\end{array}$ & 4 and 5 & $\begin{array}{l}\text { They coincided in both } \\
\text { searches }\end{array}$ & 9 & 4 & 5 \\
\hline Total articles & & & 115 & 89 & 26 \\
\hline
\end{tabular}

Afterward, each article was reviewed (in three rounds, to diminish bias) and 89 articles were excluded for the following two reasons: 1) It only measured an aspect of the MOOC, not the MOOC as a whole; and 2) It was not an empirical study of measurement or assessment. Table 3 shows the classification of the excluded articles according to these two reasons.

Table 3. Classification of the 89 excluded articles.

\begin{tabular}{|c|c|c|c|c|c|c|}
\hline $\begin{array}{l}\text { Reasons } \\
\text { for } \\
\text { exclusion }\end{array}$ & \multicolumn{3}{|c|}{$\begin{array}{l}\text { It only measured an aspect of the MOOC, not } \\
\text { the MOOC as a whole }\end{array}$} & \multicolumn{3}{|c|}{$\begin{array}{l}\text { It was not an empirical study of } \\
\text { measurement or assessment }\end{array}$} \\
\hline $\begin{array}{l}\text { Themes } \\
\text { of studies }\end{array}$ & $\begin{array}{l}\text { methodologies, } \\
\text { instructional } \\
\text { design, and } \\
\text { learning objects }\end{array}$ & $\begin{array}{l}\text { Focus on } \\
\text { the } \\
\text { students }\end{array}$ & $\begin{array}{l}\text { Focus on } \\
\text { learning } \\
\text { assessment }\end{array}$ & $\begin{array}{c}\text { Conceptual } \\
\text { study }\end{array}$ & $\begin{array}{l}\text { Predictive } \\
\text { study }\end{array}$ & $\begin{array}{c}\text { Literature } \\
\text { review }\end{array}$ \\
\hline $\begin{array}{l}\text { Number } \\
\text { of studies }\end{array}$ & 36 & 16 & 14 & 18 & 3 & 2 \\
\hline
\end{tabular}


As shown in Table 3, 66 articles were excluded because they only measured an aspect of the MOOC, not the MOOC as a whole. Of these articles, 36 focused on topics related to the MOOCs' teaching methodologies (for example, Chen, Xu, Xu, Peng, \& Xing, 2017; Inventado \& Scupelli, 2017; MuñozMerino et al., 2017; Torres-Coronas \& Vidal-Blasco, 2017), instructional design (for example, Margaryan, Bianco, \& Littlejohn, 2015) and learning objects (for example, Farhan \& Aslam, 2017). Sixteen articles focused on characteristics of the students enrolled in the MOOCs: commitment to sign up and conclude the course (Goldberg et al., 2015; Gray, 2015; Sinclair \& Kalvala, 2016), behavior during the course (Campbell, Gibbs, Najafi, \& Severinski, 2014; Kahan, Soffer, \& Nachmias, 2017; Leach \& Hadi, 2017) and emotions (Bae, Moon, \& Morrison, 2017; Leony, Muñoz-Merino, Ruipérez-Valiente, Pardo, \& Kloos, 2015; Liu et al., 2016). Finally, 14 articles focused on learning assessment; two major topics were identified: peer review (Chiou \& Shih, 2015; Estévez-Ayres, Crespo-García, Fisteus, \& Kloos, 2013; Meek, Blakemore, $\&$ Marks, 2017) and appropriate assessment of learning (Christoforaki \& Ipeirotis, 2015; Hills \& Hughes, 2016; Ruipérez-Valiente, Muńoz-Merino, Pijeira, Ruiz, \& Kloos, 2017).

Also, as shown in Table 3, 23 articles were excluded because they were not an empirical study of measurement or assessment. Of these studies, 18 were conceptual studies that reflected on different aspects of the MOOCs, for example, the quality criteria (Baldomero et al., 2015; Ghislandi, 2016); 3 were predictive studies that identified factors to foresee if a MOOC would be successful (Bonafini, Chae, Park, \& Jablokow, 2017, Greene, Oswald, \& Pomerantz, 2015, Smith, 2015), and 2 were literature review studies.

After the exclusion process, 26 articles remained. Table 4 shows the quote, the title, the type of study and the measured variables of the 26 selected articles.

Table 4. Quote, title, type of study, and measured variables in the 26 selected articles.

\begin{tabular}{llll}
\hline \multicolumn{1}{c}{ Quote } & \multicolumn{1}{c}{ Article } & Type of study & \multicolumn{1}{c}{$\begin{array}{c}\text { What is } \\
\text { measured }\end{array}$} \\
\hline $\begin{array}{l}\text { Chapman, Goodman, } \\
\text { Jawitz, and Deacon } \\
(2016)\end{array}$ & $\begin{array}{l}\text { A strategy for monitoring and evaluating } \\
\text { massive open online courses }\end{array}$ & $\begin{array}{l}\text { Qualitative case } \\
\text { study }\end{array}$ & $\begin{array}{l}\text { Quality and } \\
\text { effectiveness }\end{array}$ \\
$\begin{array}{l}\text { Sinclair, Boyatt, Foss, } \\
\text { and Rocks (2016) }\end{array}$ & $\begin{array}{l}\text { A study of user participation across different } \\
\text { delivery modes of a massive open online } \\
\text { course }\end{array}$ & $\begin{array}{l}\text { Mixed } \\
\text { descriptive }\end{array}$ & Effectiveness \\
$\begin{array}{l}\text { Yousef, Chatti, } \\
\text { Schroeder, and } \\
\text { Wosnitza (2015) }\end{array}$ & $\begin{array}{l}\text { A usability evaluation of a blended MOOC } \\
\text { environment: An experimental case study }\end{array}$ & $\begin{array}{l}\text { Quantitative } \\
\text { descriptive }\end{array}$ & Effectiveness \\
$\begin{array}{l}\text { 2017) } \text { An Xiaoming, } \\
\text { Alcock, Dufton, and }\end{array}$ & $\begin{array}{l}\text { An applicable way of teaching quality } \\
\text { evaluation based on MOOC platform }\end{array}$ & $\begin{array}{l}\text { Quantitative } \\
\text { descriptive }\end{array}$ & Quality \\
$\begin{array}{l}\text { Durusu-Tanriover } \\
\text { (2016) }\end{array}$ & $\begin{array}{l}\text { Archaeology and the MOOC: Massive, } \\
\text { open, online, and opportunistic }\end{array}$ & $\begin{array}{l}\text { Qualitative case } \\
\text { study }\end{array}$ & Effectiveness \\
$\begin{array}{l}\text { Roig-Vila et al. (2014) } \\
\text { Assessment the pedagogical quality of the } \\
\text { MOOC }\end{array}$ & $\begin{array}{l}\text { Quantitative } \\
\text { descriptive }\end{array}$ & Quality \\
$\begin{array}{l}\text { Eranki and Moudgalya } \\
\text { (2016) }\end{array}$ & $\begin{array}{l}\text { Comparing the effectiveness of self-learning } \\
\text { Java workshops with traditional classrooms }\end{array}$ & $\begin{array}{l}\text { quasi } \\
\text { experimental } \\
\text { post test }\end{array}$ & Effectiveness
\end{tabular}


Castaño, Maíz, y Garay (2015)

Loftis and Martínez

Wormser (2016)

Baldomero Ramírez-

Fernandez and

Salmerón Silvera (2015)

Tiejun (2016)

Moskal, Thompson, and Futch (2015)

Khalil, Brunner, and Ebner (2015)

Aleman De la Garza, Sancho-Vinuesa, and Gómez Zermeño (2015)

MacKay et al. (2016)

Adam et al. (2015)

Baldomero Ramírez-

Fernandez (2015)

Frick and Dagli (2016)

Hsieh, M.-Y. (2016)

(Rieber, 2017)

Baldomero RamírezFernandez (2015b)

Yepes-Baldó et al. (2016)

Gómez Hernandez, Monge López, and Sebastian Heredero (2016)

(Henderikx, Kreijins \& Kalz, 2017)
Design, Motivation and Performance in a Cooperative MOOC Course

Developing Online Information Literacy Instruction for the Undergraduate Art Student: A Collaborative Approach in the Context of the Framework for Information Literacy

Edutool $^{\oplus}$ : A tool for evaluating and accrediting the quality of MOOCs

Empirical research on the effectiveness of MOOCs in developing design students on sino-foreign cooperation university programs

Enrollment, engagement, and satisfaction in the Blendkit faculty development open, online course

Evaluation grid for xMOOCs

Indicators of pedagogical quality for the design of a massive open online course for teacher training

Massive open online courses as a tool for global animal welfare education

Massive open online nutrition and cooking course for improved eating behaviors and meal composition

MOOC appraisal: A quality perspective

MOOCs for Research: The Case of the Indiana University Plagiarism Tutorials and Tests

Online learning era: Exploring the most decisive determinants of MOOCs in Taiwanese higher education Participation patterns in a massive open online course (MOOC) about statistics Proposal quality certification of educational Spanish MOOC courses offer conducted by the National Institute of Educational

Technologies and Teacher Training. Quality indicators: developing "MOOCs" in the European Higher Education Area

Quality of a MOOC inclusion on education: implementation of various instruments and indicators

Refining success and dropout in massive open online courses based on the intentionbehavior gap
Quantitative ex post facto Effectiveness prospective

Qualitative case study

Quality

Quantitative instrumental

Quality

Qualitative case study

Effectiveness

Qualitative case study

Effectiveness

Quantitative

instrumental

Quality

Quantitative instrumental

Quality

Quantitative

quasi

experimental

pre-post-test

Quantitative

quasi

experimental

pre-post-test

Quantitative

descriptive

Qualitative case study

Quality and

Effectiveness

Quantitative instrumental

Quality

Quantitative

descriptive

Quality

Quantitative

descriptive

Quality

Quantitative instrumental

Quality

Qualitative case study

Quality

Quantitative ex post facto prospective
Effectiveness 
Masanet et al. (2014)

(Mengual-Andrés, Lloret Catala, \& Roig Vila, 2015)
Reflections on a massive open online life cycle assessment course

Validation of the Questionnaire of Quality Assessment of Online Courses adapted to MOOC
Quantitative

quasi

experimental

Effectiveness

pre-post-test

Quantitative

instrumental
Quality

\section{Steps 4 \& 5. Classification Scheme, Data Extraction and Mapping of Studies}

For the data analysis, from the first two sets of research questions (RQ1 and RQ2), a tabulation was decided and then a percentile analysis performed. For the third set of research questions (RQ3) the articles were classified by types of study, based on the proposal by Montero and León (2007), and then were described in comparative tables for each item. The search, the gathering and the analysis of data for the systematic mapping study were concluded with these procedures.

\section{RESULTS}

In this section are presented the obtained results when performing the review of the literature for this mapping divided into the three groups of research questions.

\section{(RQ1): Context of the Publication}

In this subsection are presented the obtained results related to the first set of research questions referring to the context of the publication. The distribution of the publications is analyzed by: (1) country of publication, (2) year of publication, (3) magazines of publication with more frequency, and (4) by country of affiliation of the first author. With respect to the country of publication (see Table 5), it was found that the published work is only distributed in seven countries. The country that concentrated the most amount of publications was Spain with 27\%, followed by the United States with 23\%, the United Kingdom with 19\%, and Germany with $15 \%$. Also, it is observed that the three other countries concentrate only $4 \%$ of the publications respectively (Brazil, Canada, Switzerland and Turkey). It should be noted that the majority of articles are developed first in Europe, then in North America and in a minimum proportion in South America.

Table 5. Countries by articles publication.

\begin{tabular}{cc}
\hline Country & $\%$ \\
\hline Spain & $27 \%$ \\
United States & $23 \%$ \\
United Kingdom & $19 \%$ \\
Germany & $15 \%$ \\
Brazil & $4 \%$ \\
Canada & $4 \%$ \\
Switzerland & $4 \%$ \\
Turkey & $4 \%$ \\
\hline
\end{tabular}

The search of articles was performed in the 2012-2017 period. When analyzing the publications by year of publication (see Figure 2), it was found that there were no publications about quality and effectiveness between the years of 2012 and 2013. This could be because, in 2012, MOOCs were massified as it was previously mentioned when analyzing Figure 1. Besides, it can be observed in Figure 2 that in 2014, 8\% of the studies were published, $38 \%$ in $2015,42 \%$ in 2016 , and $12 \%$ in 2017 . This distribution of articles 
justifies the value of our study. As mentioned before, the revisions of previous literature analyze only until 2015. According to our search, $52 \%$ of the articles with the specific characteristics established in the Methodology section were published in 2016-2017. This is half of the empirical articles about the measurement of quality and effectiveness in the MOOCs.

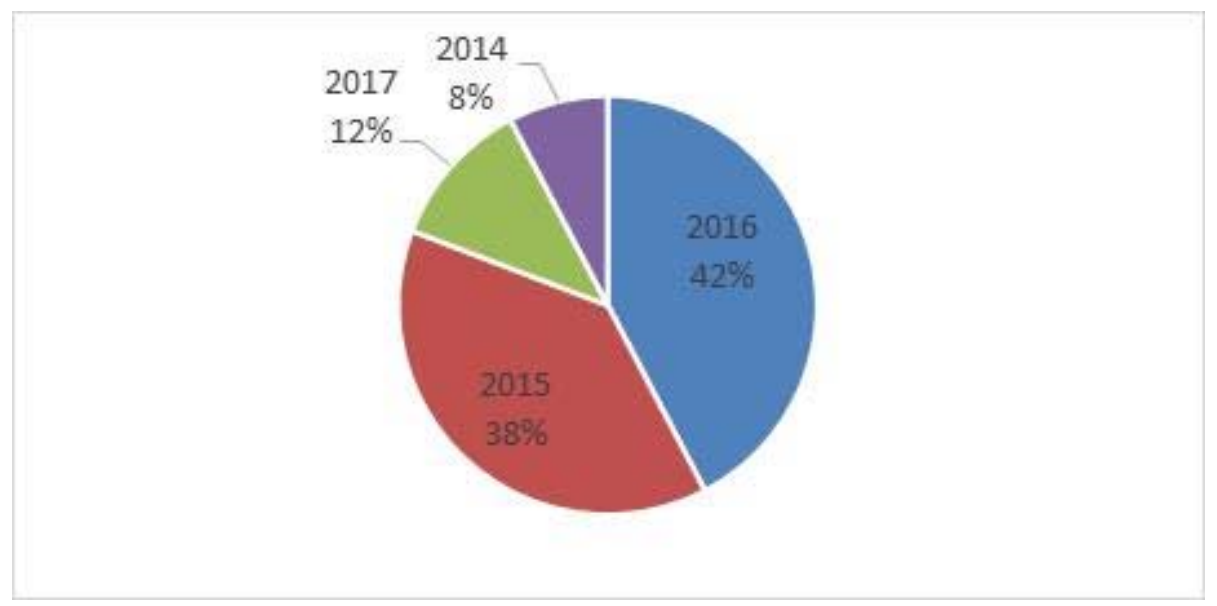

Figure 2. Distribution of publications by year

In relation to the magazines, it was identified that "La Revista Iberoamericana de Educación a Distancia" and "the International Journal of Emerging Technologies in Learning", are the ones that concentrate the higher number of articles with two publications in each. Additionally, other characteristics of the magazines are reported such as that $32 \%$ of the studies were published in magazines that were in the Q1 and 36\% between Q2 and Q3 of the Rankings: Scimago Journal Rank or Journal Citation Report and that $60 \%$ of these articles are open access.

Finally, in relation to the places where the studies were developed, which were measured through the filiation of the principal researcher, it was found that 31\% of them were held in Spain and 27\% in the United States (Table 6, Figure 3). It is observed here, as in the country of publication case, that Europe concentrates the highest amount of publications, followed by North America and Asia.

Table 6. Country of filiation of the principal researcher.

\begin{tabular}{cc}
\hline Country & $\%$ \\
\hline Spain & $31 \%$ \\
United States & $27 \%$ \\
China & $12 \%$ \\
United Kingdom & $8 \%$ \\
Germany & $4 \%$ \\
Austria & $4 \%$ \\
India & $4 \%$ \\
Mexico & $4 \%$ \\
South Africa & $4 \%$ \\
Netherlands & $4 \%$ \\
\hline
\end{tabular}




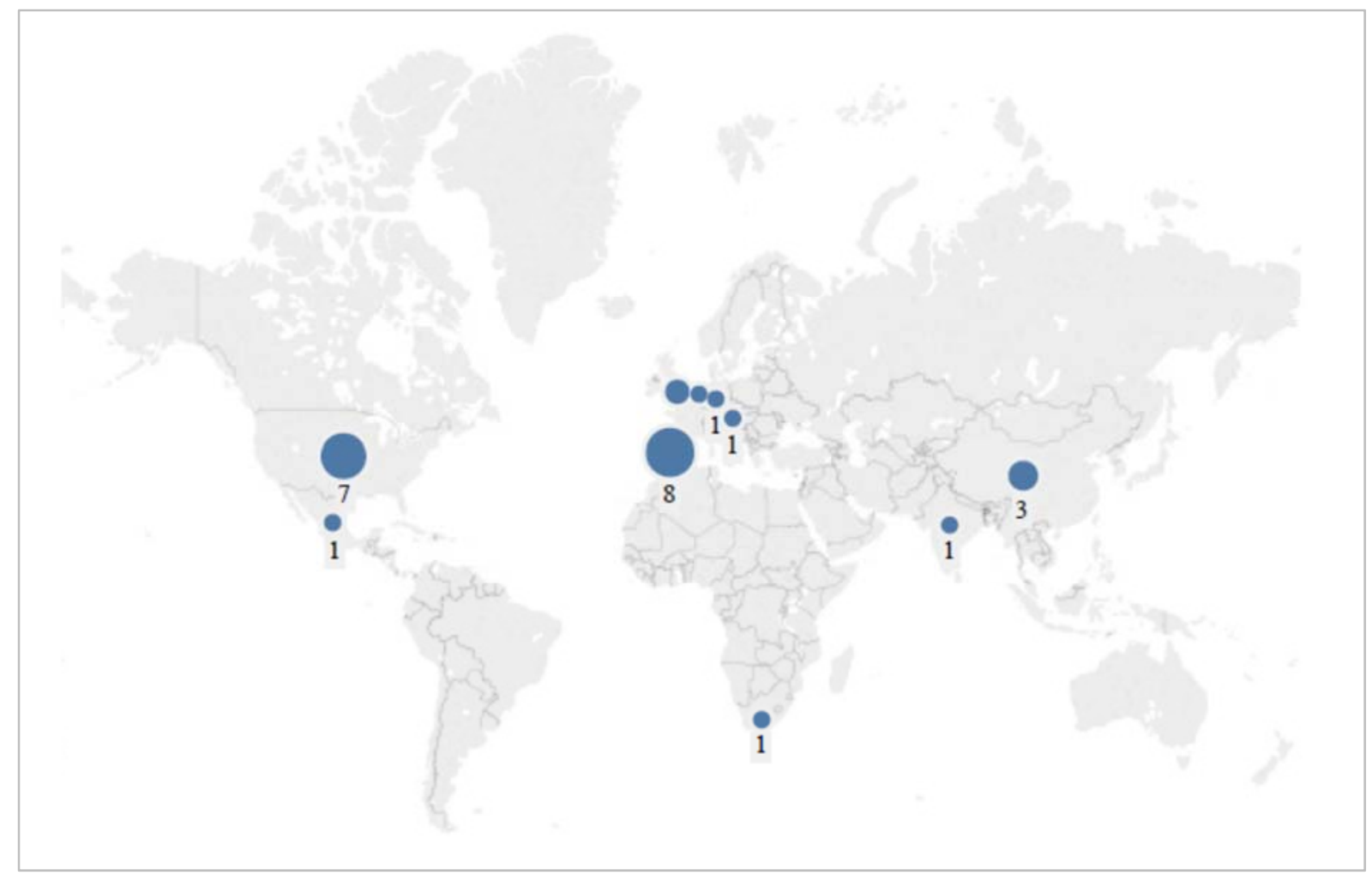

Figure 3. Country of filiation of the principal researcher.

(RQ2) Type of Developing Institutions and Distributing Platforms of MOOCs

This section analyzes the type of developing institutions and distributing platforms of MOOCs in the studied publications. According to MOOC developing institutions, (see Figure 4), it was identified that $54 \%$ were universities, $8 \%$ government institutions, and $4 \%$ independent associations. Furthermore, 34\% of the studies do not mention the source of the MOOCs. This is usually because these studies were generally made in a group of MOOCs where the main interest was the topic or some common characteristic among them independently from their or its origin.

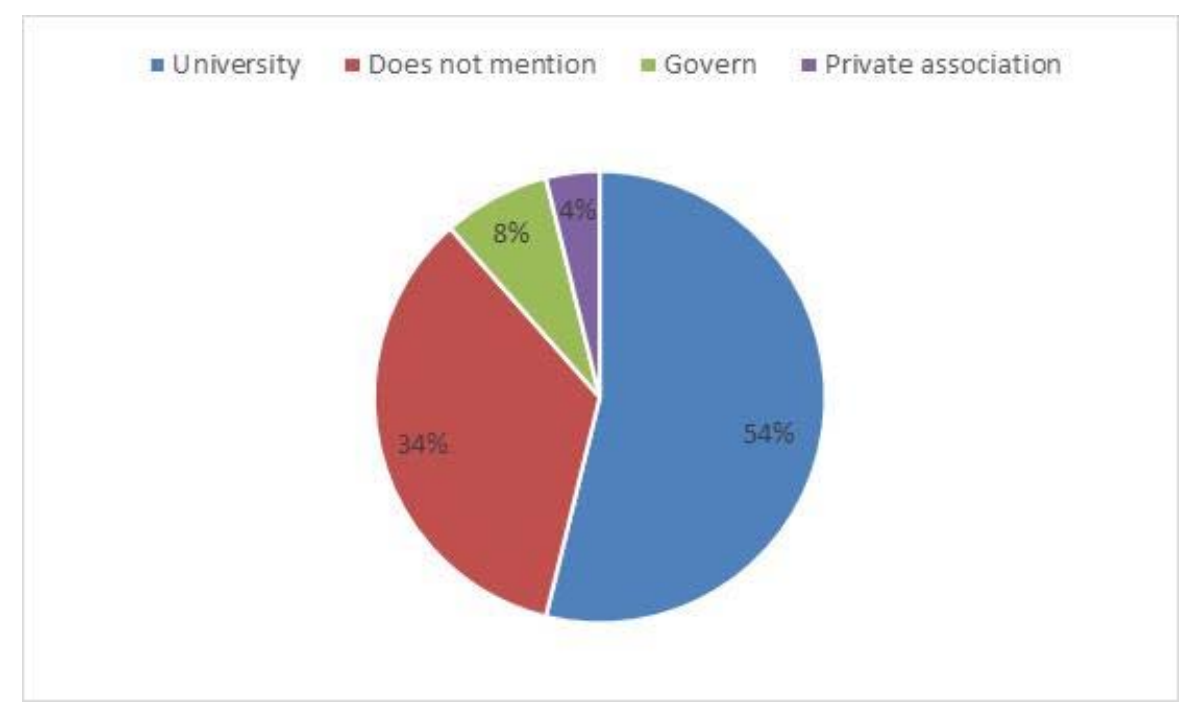

Figure 4. Developing Institutions of MOOCs 
Regarding the distributing platforms of the MOOC (Table 7), the following is reported: $31 \%$ were by Coursera, Edx with 14\%, and Udacity and Canvas with 7\% each one. Another important figure is that 9\% corresponds to studies performed with the own institutions' platforms.

Table 7. Percentage of studied platforms.

\begin{tabular}{cc}
\hline Plataform & $\%$ \\
\hline Coursera & $31 \%$ \\
EdX & $14 \%$ \\
Does not report & $14 \%$ \\
University's own & $9 \%$ \\
Canvas Network & $7 \%$ \\
Udacity & $7 \%$ \\
Miríada X & $6 \%$ \\
L2P-bMOOC & $3 \%$ \\
Lynda.com & $3 \%$ \\
FutureLearn & $3 \%$ \\
UNX & $3 \%$ \\
\hline
\end{tabular}

\section{(RQ3) Characteristics of the Empirical Studies}

This section analyzes the distribution of the publications by type of study, the more frequently used indicators to measure the effectiveness, and the more frequently used focus points (approaches) to measure quality.

\section{Types of Studies}

Each publication was classified, using as reference the article from Montero and León (2007), with the purpose of systematizing the results about the type of studies. Table 8 shows the distribution of publications that measure quality, effectiveness, and both (quality and effectiveness as a set), by type of study.

About the distribution of publications by measured variable, it is observed that $50 \%$ of the articles measure the quality variable, another $42 \%$ the effectiveness, and $8 \%$ quality and effectiveness as a set. In respect to the distribution of publications by type of study, it can be observed that $27 \%$ of the articles are qualitative (first row), $69 \%$ are quantitative (from the second to the sixth row), and that $4 \%$ of the articles are mixed studies (seventh row).

Table 8. Classification by types and object of studies.

\begin{tabular}{|c|c|c|c|c|c|}
\hline $\begin{array}{l}\text { Types of } \\
\text { study }\end{array}$ & $\begin{array}{c}\text { Types of study and } \\
\text { definition }\end{array}$ & Quality & Effectiveness & $\begin{array}{l}\text { Quality and, } \\
\text { effectiveness }\end{array}$ & $\begin{array}{c}\text { Total, } \\
\text { genera } \\
1\end{array}$ \\
\hline $\begin{array}{l}\text { Qualitative } \\
\text { case study }\end{array}$ & $\begin{array}{l}\text { Describes strategies referred } \\
\text { to a single element: a } \\
\text { person, a group, an } \\
\text { organization. }\end{array}$ & 2 & 3 & 2 & $\begin{array}{c}7 \\
(27 \%)\end{array}$ \\
\hline $\begin{array}{l}\text { Quantitative } \\
\text { quasi } \\
\text { experimental } \\
\text { post-test with } \\
\text { two groups }\end{array}$ & $\begin{array}{l}\text { One treated group and } \\
\text { another of non-equivalent } \\
\text { control; both measured at } \\
\text { the same time (only post- } \\
\text { test). }\end{array}$ & 0 & 1 & 0 & $\begin{array}{c}1 \\
(4 \%)\end{array}$ \\
\hline
\end{tabular}




\begin{tabular}{|c|c|c|c|c|c|}
\hline $\begin{array}{l}\text { Quantitative } \\
\text { quasi } \\
\text { experimental } \\
\text { pre-post-test }\end{array}$ & $\begin{array}{l}\text { Measures the dependent } \\
\text { variable before and after the } \\
\text { intervention. }\end{array}$ & 0 & 3 & 0 & $\begin{array}{c}3 \\
(12 \%)\end{array}$ \\
\hline $\begin{array}{l}\text { Quantitative } \\
\text { descriptive }\end{array}$ & $\begin{array}{l}\text { Applies systematic } \\
\text { observation by using a } \\
\text { codified arbitrary system. }\end{array}$ & 4 & 1 & 0 & $\begin{array}{c}5 \\
(19 \%)\end{array}$ \\
\hline $\begin{array}{l}\text { Quantitative } \\
\text { ex post facto } \\
\text { prospective }\end{array}$ & $\begin{array}{l}\text { Begins by registering the } \\
\text { values of an independent } \\
\text { variable and then by } \\
\text { measuring the dependent } \\
\text { one. }\end{array}$ & 0 & 2 & 0 & $\begin{array}{c}2 \\
(8 \%)\end{array}$ \\
\hline $\begin{array}{l}\text { Quantitative } \\
\text { instrumental }\end{array}$ & $\begin{array}{l}\text { Notes the development of } \\
\text { new procedures, tools, } \\
\text { instruments or tests. }\end{array}$ & 7 & 0 & 0 & $\begin{array}{c}7 \\
(27 \%)\end{array}$ \\
\hline $\begin{array}{c}\text { Mixed } \\
\text { descriptive }\end{array}$ & $\begin{array}{l}\text { Uses a qualitative method } \\
\text { and another quantitative } \\
\text { one. }\end{array}$ & 0 & 1 & 0 & $\begin{array}{c}1 \\
(4 \%)\end{array}$ \\
\hline Total, general & & $\begin{array}{l}13( \\
\%)\end{array}$ & $11(42 \%)$ & $2(8 \%)$ & $\begin{array}{c}26 \\
(100 \% \\
)\end{array}$ \\
\hline
\end{tabular}

By observing Table 8 it can be noted that the most frequent type of study is the qualitative case study ( 7 publications, 27\%), as 2 of these publications measure the quality, 3 measure the effectiveness, and 2 measures jointly quality and effectiveness. It is also observed that the other most frequent study is the quantitative instrumental (7 publications, 27\%) and that within this, all publications measure the quality. On the other hand, it is shown that the third most frequent one is the quantitative descriptive (5 publications, 19\%), with 4 of them measuring quality and only one measuring effectiveness. Lastly, the fourth most frequent study (3 publications, 12\%) is quantitative quasi-experimental pre-post-test, with all of these articles measuring the effectiveness. So, it is observed that the most utilized types of studies to measure quality are quantitative instrumental (7 publications) and quantitative descriptive (4 publications), and qualitative case study (2 publications). Moreover, the most frequent study types to measure effectiveness were quantitative quasi-experimental pre-post-tests (3 publications) and qualitative case study (3 publications) respectively. Finally, the most used type for measuring jointly quality and effectiveness is the qualitative case study (2 publications). This publication distribution is interesting for the researchers because it allows having a general view of the most frequently utilized methodologies.

\section{Effectiveness of Indicators}

It was identified that investigations can use a combination of indicators that at the end report if the course was effective. These indicators could contemplate:

$>$ Performance, that can be expressed as an achievement of the objectives, change of knowledge or attitude, grades, or as the achievement itself.

$>$ Teaching methodology that includes the design, assessment, and course contents.

$>$ Retention or desertion (dropout) from the course and the commitment. These indicators pretend to measure that students do not drop out from the course.

$>$ Perceptions of motivation/satisfaction, which have to do with the emotions that students feel during or at the end of the course.

$>$ Culmination or certification from the course. 
Table 9 shows the frequency of use, of this group of indicators, in the studies that assess effectiveness.

Table 9. Frequency of use of the five groups of indicators in the eleven studies that evaluate the effectiveness.

\begin{tabular}{|c|c|c|c|c|c|}
\hline \multirow[b]{2}{*}{ Article } & \multicolumn{5}{|c|}{ Group of indicators to evaluate the effectiveness } \\
\hline & Efficiency & $\begin{array}{c}\text { Teaching } \\
\text { Methodology }\end{array}$ & $\begin{array}{l}\text { Retention, } \\
\text { Commitment } \\
\text { or Dropout }\end{array}$ & $\begin{array}{l}\text { Perceptions } \\
\text { of } \\
\text { motivation/ } \\
\text { satisfaction }\end{array}$ & $\begin{array}{c}\text { Course } \\
\text { culmination }\end{array}$ \\
\hline Eranki and & & & & & \\
\hline $\begin{array}{c}\text { Moudgalya } \\
(2016)\end{array}$ & 1 & 1 & 0 & 0 & 0 \\
\hline $\begin{array}{c}\text { MacKay et al. } \\
\text { (2016) }\end{array}$ & 1 & 0 & 1 & 1 & 1 \\
\hline $\begin{array}{l}\text { Adam et al. } \\
\text { (2015) }\end{array}$ & 1 & 0 & 0 & 0 & 0 \\
\hline $\begin{array}{l}\text { Masanet et al. } \\
\text { (2014) }\end{array}$ & 1 & 0 & 1 & 0 & 0 \\
\hline Tiejun (2016) & 0 & 0 & 1 & 1 & 0 \\
\hline $\begin{array}{l}\text { Alcock et al. } \\
\text { (2016) }\end{array}$ & 0 & 0 & 0 & 0 & 1 \\
\hline $\begin{array}{l}\text { Moskal et al. } \\
(2015)\end{array}$ & 0 & 0 & 1 & 0 & 0 \\
\hline $\begin{array}{l}\text { Yousef et al. } \\
(2015)\end{array}$ & 0 & 1 & 0 & 0 & 0 \\
\hline $\begin{array}{c}\text { Castaño et al. } \\
\text { (2015) }\end{array}$ & 1 & 1 & 0 & 0 & 1 \\
\hline $\begin{array}{c}\text { Sinclair et al. } \\
\text { (2016) }\end{array}$ & 1 & 1 & 0 & 1 & 0 \\
\hline $\begin{array}{l}\text { (Henderikx } \\
\text { et al., 2017) }\end{array}$ & 0 & 0 & 0 & 1 & 1 \\
\hline Percentage & $55 \%$ & $36 \%$ & $36 \%$ & $36 \%$ & $36 \%$ \\
\hline
\end{tabular}

One of the most important results that can be observed in Table 9 is that $54 \%$ of the articles used efficiency indicators. On the other hand, another important result is that the other four indicators (Teaching methodology; Retention, Commitment or Dropout; Perceptions of motivation/satisfaction; and Course culmination) have the same percentage: $36 \%$ respectively.

\section{Quality Approach}

It was identified within the last 26 analyzed articles that in respect to the assessment of quality, more complex models, that contemplate dimensions either with criteria or indicators, were used. Therefore, it can be observed that the study of quality results more complex and profound than the effectiveness study. 
Table 10. Frequency of use of the seven criteria in the eleven approaches to assess the quality.

\begin{tabular}{|c|c|c|c|c|c|c|c|}
\hline $\begin{array}{l}\text { Approach/ } \\
\text { Quote }\end{array}$ & $\begin{array}{l}\text { Pedago- } \\
\text { gical }\end{array}$ & $\begin{array}{l}\text { Functional } \\
\text { from the } \\
\text { platform }\end{array}$ & $\begin{array}{c}\text { Platforms or } \\
\text { Technological } \\
\text { Systems }\end{array}$ & Time & $\begin{array}{l}\text { Intrinsic } \\
\text { of the } \\
\text { student }\end{array}$ & $\begin{array}{l}\text { Interaction } \\
\text { with the } \\
\text { professor }\end{array}$ & Effect \\
\hline $\begin{array}{c}\text { E1: Baldomero } \\
\text { Ramírez- } \\
\text { Fernandez } \\
\text { (2015a, 2015b), } \\
\text { Baldomero } \\
\text { Ramírez- } \\
\text { Fernandez y } \\
\text { Salmerón Silvera } \\
\text { (2015) }\end{array}$ & 1 & 1 & 0 & 0 & 0 & 0 & 1 \\
\hline $\begin{array}{l}\text { E2: Mengual- } \\
\text { Andrés et al. } \\
\text { (2015), Roig-Vila } \\
\text { et al. (2014) based } \\
\text { on Arias (2007) }\end{array}$ & 1 & 1 & 0 & 1 & 1 & 0 & 0 \\
\hline $\begin{array}{l}\text { E3: Aleman De la } \\
\text { Garza et al. } \\
\text { (2015), Gómez } \\
\text { Hernandez et al. } \\
\text { (2016) }\end{array}$ & 1 & 1 & 1 & 1 & 0 & 0 & 0 \\
\hline $\begin{array}{l}\text { E4: Khalil et al. } \\
\qquad(2015)\end{array}$ & 1 & 1 & 1 & 0 & 0 & 1 & 0 \\
\hline $\begin{array}{l}\text { E5: Yepes-Baldó } \\
\text { et al. (2016) }\end{array}$ & 1 & 1 & 1 & 0 & 0 & 0 & 0 \\
\hline $\begin{array}{c}\text { E6: Zhuo y } \\
\text { Xiaoming (2017) }\end{array}$ & 1 & 0 & 0 & 0 & 0 & 0 & 0 \\
\hline $\begin{array}{l}\text { E7: Rieber (2017) } \\
\text { E8: Loftis y }\end{array}$ & 1 & 0 & 1 & 1 & 0 & 0 & 1 \\
\hline $\begin{array}{c}\text { Martínez } \\
\text { Wormser (2016) }\end{array}$ & 1 & 0 & 0 & 1 & 1 & 0 & 0 \\
\hline $\begin{array}{l}\text { E9: Chapman } \\
\text { et al. (2016) }\end{array}$ & 1 & 0 & 1 & 0 & 0 & 1 & 0 \\
\hline $\begin{array}{l}\text { E10: Frick and } \\
\text { Dagli (2016) }\end{array}$ & 1 & 0 & 0 & 0 & 1 & 0 & 0 \\
\hline $\begin{array}{c}\text { E11: Hsieh, M.- } \\
\text { Y. (2016). }\end{array}$ & 1 & 1 & 0 & 0 & 0 & 1 & 0 \\
\hline Total & 11 & 6 & 5 & 4 & 3 & 3 & 2 \\
\hline Percentage & $100 \%$ & $55 \%$ & $45 \%$ & $36 \%$ & $27 \%$ & $27 \%$ & $18 \%$ \\
\hline
\end{tabular}

When analyzing the fifteen studies regarding quality, eleven quality approaches were identified in order to assess them. As seen in the first column of Table 10, the eleven quality approaches are identified and are called E1 to E11 respectively. As it can be observed in the article's quote, in each of the approaches (column two of the table), in approach 1 (E1), three studies from the analyzed group from Baldomero RamírezFernandez (Baldomero Ramírez-Fernandez y Salmerón Silvera, 2015; Baldomero Ramírez-Fernandez, 2015a, 2015b;) are grouped. In approach 2 (E2), it can be observed that two articles from the analyzed studies are found (Mengual-Andrés et al., 2015; Roig-Vila et al., 2014) and that these two take as reference the Arias study (2007). Moreover, two articles of the analyzed studies (Aleman De la Garza et al., 2015; Gómez Hernandez et al., 2016), are grouped in approach E3 while there is just an article in the rest of the 
approaches (E4-E10), As it can be seen, the first three approaches (E1-E3) are the ones more used within the 2012-2017 period.

The eleven quality approaches were classified according to seven different groups of appraisal criteria that take into consideration the reach and the objective of the study. As previously mentioned, this type of groupings has not been performed in previous literature revisions. These seven different groups of appraisal criteria are:

Pedagogical criteria: this groups the criteria that contemplate the teaching methodology, the design of the course from objectives to assessment, the instructional design, the quality and relevance of the contents or of the learning objectives. About this, it was observed that the approaches can deal with all aspects in a general manner or with some of them.

$>$ Functional criteria of the platform: this one groups the criteria that valuate the functions that incorporate the platforms in order to complement the teaching process. For example: the utilization of tools such as video players, chats, forums, mobile applications, etc. Also, in this aspect can be assessed the correct use of these tools.

$>$ Platforms or technological systems criteria: this groups the criteria that evaluate the solidity of the platform, the capacity to be accessible the 24 hours of the 365 days a year, the timely technological support for the student, accessibility, compatibility between technologies, besides other similar topics.

$>$ Time criteria: this group of criteria is associated with two main characteristics: the presentation and the fulfillment with a chronogram and the speed of how doubts are responded and support are given to the student.

$>$ Intrinsic criteria of the student: this criteria group is associated to the valuation of emotions or perceptions that the student manifests before, during, or at the end of the course. These can be: motivation, satisfaction, or commitment.

$>$ Interaction with the teacher criteria: this group of criteria refers to the student finding an opportunity of communication with the professor, which can be through the same MOOC's platform as the timely answer from the student.

$>$ Effect criteria: this group of criteria is geared towards assessing if the MOOC impacted the student in some progress, as in the betterment of the student's knowledge or competences.

Table 10 shows the frequency of use of this group of criteria in the eleven approaches to assess quality. The first interesting trend that is observed is that in all approaches (100\%), the pedagogical criteria are considered. This seems to be because, in the education field, pedagogical criteria are the base of any type of course development. The second interesting trend is that $55 \%$ of the approaches consider the functional criteria of the platform. Finally, it can be observed that the rest of the groups have percentages equal or lower than $45 \%$ in the following order: the platforms or technological systems criteria $(45 \%)$, Time criteria $(36 \%)$, Intrinsic criteria of the student and Interaction with the teacher criteria (27\% respectively), and Effect criteria (18\%).

As previously mentioned, the first three approaches (E1-E3) are the more utilized approaches in the 20122017 period. Each of these approaches is described next.

$>$ Approach E1: This E1 approach, from Baldomero Ramírez-Fernandez \& Salmerón Silvera (2015), presents EduTool ${ }^{\oplus}$, a registered trademark in the Spanish Office of Trademarks and Patents which proposal is based on Spain's Regulations (Normas Españolas UNE 66181). The valuation categories are: Recognition of the formation of employability, which contains 6 items; Learning methodology, which contains 43 items; and Accessibility with 21 items. 
Approach E2: The E2 approach is based on the Arias Masa doctoral thesis (2007). Its proposal is directed towards the assessment of virtual courses and, even though is not specific for the MOOCs, it has been adapted and taken as reference. The proposed categories are: Pedagogical Quality (Teaching guide, Methodology, Organization of the contents, Quality of the contents, Teaching resources, Capacity to motivate, Multimedia elements, Language style, Discrimination and values, User singularity); Technical Quality (Security of information, Technical compatibility, Integration with other systems, Modular and scalable); Management (System's communication, Interaction among participants, Flows of information); Usability (Surfing ease, Legibility of information, Aesthetic Quality of the interface); and General Assessment (Non-evaluated aspects). What is interesting about this approach is how long it has existed and how, for such reason, it has been used in diverse investigations and the level of assessment detail.

> Approach E3: The E3 approach, from Aleman De la Garza et al. (2015) proposes 50 indicators to assess the pedagogical quality of the design of a MOOC. These are grouped into 4 categories and 15 subcategories. The four assessment categories are: Pedagogical (Contents, pedagogical focus, tutorials, evaluation, adequation and adaptation to the users, ability for motivation, and resources); Functional (Ease of use, autonomy and control from the user, and functionality of the documentation); Technological (Interaction and surfing dialogues, visual environment, design and technology, and versatility; and Time (Presentation of the exams, performing activities, doing exercises, studying topics, calendar, and participation in forums and discussions). The criteria were validated by the Delphi method by 55 experts and the final instrument was applied in 12 MOOCs.

\section{DISCUSSIONS AND CONCLUSION}

This article analyzed how quality and effectiveness were measured in MOOCs through empirical studies between 2012 and 2017. A systematic mapping study was performed by using Scopus and Web of Science databases with keywords, and their equivalents, to MOOC, measurement, effectiveness, and quality. The articles were analyzed according to: (1) context of the publication, (2) type of developing institution and distributing platform of the MOOC, and (3) characteristics of the empirical studies.

Within the context of the publication, it was found that the majority of the articles are published in Europe, followed by North America and in a minimum proportion in South America. It was also observed that the country of filiation of the first author is concentrated in Europe followed by North America and Asia. Related to the developing institutions of the MOOC, it was identified that $54 \%$ of the developing institutions were universities, $8 \%$ government institutions and $4 \%$ independent associations and about the platforms that distributed the MOOC, it can be noted that $31 \%$ are of Coursera, $14 \%$ of Edx, $7 \%$ of Canvas Network and the $7 \%$ of Udacity.

Many interesting trends were found concerning the characteristics of the empirical studies. Within the type of studies, it can be observed that the most utilized, by frequency order, to measure the quality are quantitative instrumental, quantitative descriptive, and qualitative case study. On the other hand, the most frequent types of study to measure effectiveness are quantitative quasi-experimental, pre-post-tests and qualitative case study. Lastly, the type of study most used in order to measure quality and effectiveness as a set was the qualitative case study. This distribution of publications is interesting for the researchers because it allows having a general view of the most frequently utilized methodologies used.

Regarding the use of indicators in the studies that assess effectiveness, it can be observed that $55 \%$ of the articles used efficiency indicators, and that the other four indicators (Teaching methodology; Retention, Commitment or Dropout; Perceptions of motivation/satisfaction; and Course culmination) have the same 
percentage of use: $36 \%$ respectively. When analyzing the fifteen studies about quality, eleven approaches to evaluate quality were at first identified. The three most used approaches in the period were from Baldomero Ramírez-Fernandez et al. (2015, 2015a, 2015b), from Arias (2007), and the Aleman De la Garza et al. (2015) approach. Also, interesting trends were observed as to the frequency in the use of criteria in these eleven approaches. It was noted that pedagogical criteria are considered in all approaches (100\%) while 55\% of the approaches consider functional criteria of the platform and $45 \%$ of the criteria of platforms or technological systems, while the remainder of the groups of criteria have percentages lower than $45 \%$ in the following order: Time criteria (36\%), Intrinsic criteria of the student (27\%), Interaction with the teacher criteria $(27 \%)$ and Effect criteria (18\%).

Considering the principal question of this study, which refers to how quality and effectiveness are measured in the MOOCs, it is concluded that effectiveness is measured mainly by indicators at the beginning and the end of the MOOC, which are mostly oriented towards the performance of the student in the classroom. In the case of quality, it is observed that courses are principally assessed in respect to fulfilling certain criteria, which can encompass different aspects, particularly pedagogical and functional criteria of the platform, which are present in all the cases. It is not observed in the literature a close link between quality and effectiveness. This is important in order to understand the quality standards that contribute to courses becoming more effective. On the other hand, on behalf of quality, student evaluations are not observed, the judgments are mainly made by the experts.

Authors' Note: The study has been recorded in the framework of Project 266632 "Binational Laboratory for the Intelligent Management of Energy Sustainability and Technological Training", with financing from the CONACYT-SENER Energy Sustainability Fund (call: S0019ᄀ2014ᄀ01).

\section{BIODATA and CONTACT ADDRESSES of AUTHORS}

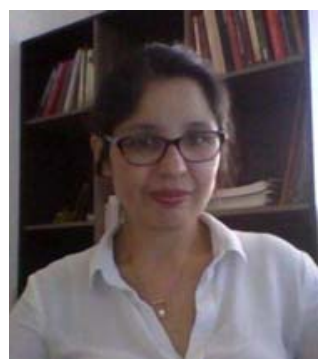

Rocio QUILIANO-TERREROS is a Research Manager at Universidad Privada del Norte. Graduated in Information Science and Librarianship. Her academic interest areas are distant and massive education, quality indicators in education, science and technology indicators. She has extensive experience analyzing quality indicators of university ranking and rating.

\section{Rocio QUILIANO-TERREROS}

Department of Research, Universidad Privada del Norte, 15023, Lima, Peru

Phone: +5116044720

E-mail: rocio.quiliano@upn.edu.pe

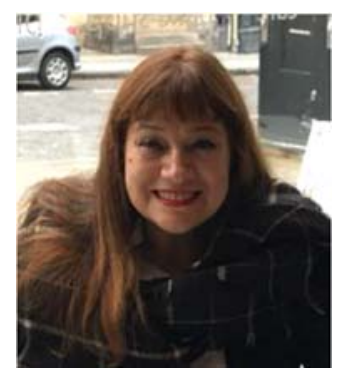

Darinka RAMIREZ-HERNANDEZ is currently in a position as ProfessorResearcher at the School of Humanities and Education of the Tecnologico de Monterrey, Monterrey Campus. She is a researcher in the area of Innovation in Education. Her main line of research is about strategies and the use technology for education. She has written several chapters and articles in international journals. 


\section{Darinka RAMIREZ-HERNANDEZ}

Director of Education Department, School of Humanities and Education

Address: Tecnologico de Monterrey, 64849, Monterrey, Mexico

Phone: +52 (81) 8358-2000,

E-mail: darinka@tec.mx

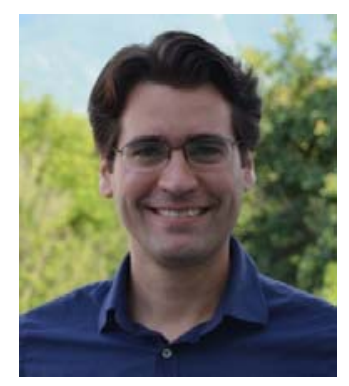

Pablo BARNIOL is currently in a position as Professor-Researcher at the School of Humanities and Education of the Tecnologico de Monterrey, Monterrey Campus. $\mathrm{He}$ is a researcher in the area of Science Education. His main line of research is about the conceptual understanding of university students in science. He has published 21 articles in international journals.

Pablo BARNIOL

Education Department, School of Humanities and Education

Address: Tecnologico de Monterrey, 64849, Monterrey, Mexico

Phone: +52 (81) 8358-2000,

E-mail: pablo.barniol@tec.mx

\section{REFERENCES}

Adam, M., Young-Wolff, K. C., Konar, E., \& Winkleby, M. (2015). Massive open online nutrition and cooking course for improved eating behaviors and meal composition. International Journal of Behavioral Nutrition and Physical Activity, 12, 143.

Alcock, S. E., Dufton, J. A., \& Durusu-Tanriover, M. (2016). Archaeology and the MOOC: Massive, open, online, and opportunistic. Journal of Social Archaeology, 16(1), 3-31.

Aleman De la Garza, L., Sancho-Vinuesa, T., \& Gómez Zermeño, M. (2015). Indicators of pedagogical quality for the design of a massive open online course for teacher training. Universities and Knowledge Society Journal, 12(1), 104-118.

Arias Masa, J. (2008). Evaluación de la calidad de Cursos Virtuales: Indicadores de Calidad y construcción de un cuestionario a medida. Aplicación al ambito de asignaturas de Ingeniería Telematica [Evaluation of the quality of Virtual Courses: Quality Indicators and construction of a customized questionnaire. Application to the field of Telematics Engineering subjects] (Doctoral dissertation). Universidad de Extremadura, Spain.

Bae, S.-Y., Moon, J., \& Morrison, J. R. (2017). Design of engineering courses as a service: Emotions, senses and implementation. International Journal of Engineering Education, 33(5), 1561-1574.

Baldomero Ramírez-Fernandez, M. (2015a). MOOC appraisal: A quality perspective. Revista Iberoamericana de Educación a Distancia, 18(2), 171-195.

Baldomero Ramírez-Fernandez, M. (2015b). Proposal quality certification of educational Spanish MOOC courses offer conducted by the National Institute of Educational Technologies and Teacher Training. International Journal of Educational Research and Innovation, 3, 121-133.

Baldomero Ramírez-Fernandez, M., \& Salmerón Silvera, J. L. (2015). Edutool ${ }^{\bullet}$ : a tool for evaluating and accrediting the quality of Moocs [EduTool ${ }^{\circ}$ : Un instrumento para la evaluación y acreditación de la calidad de los MOOCs]. Educación XX1, 18(2), 97-123. 
Baldomero Ramírez-Fernandez, M., Salmerón Silvera, J. L., \& López Meneses, J. L. (2015). Comparative between quality assessment tools for MOOCs: ADECUR vs Standard UNE 66181: 2012 [Comparativa entre instrumentos de evaluación de calidad de cursos MOOC: ADECUR vs Normas UNE 66181:2012]. RUSC. Universities and Knowledge Society Journal, 12(1), 131144 .

Baturay, M. H. (2015). An Overview of the World of MOOCs. Procedia - Social and Behavioral Sciences, 174(Supplement C), 427-433.

Bozkurt, A., Akgün-ozbek, E., \& Zawacki-Richter, O. (2017). Trends and patterns in massive open online courses: Review and content analysis of research on MOOCs (2008-2015). International Review of Research in Open and Distance Learning, 18(5), 118-147. https://doi.org/10.19173/irrodl.v18i5.3080

Bozkurt, A., Keskin, N. O., \& Waard, I. de. (2016). Research Trends in Massive Open Online Course (MOOC) Theses and Dissertations: Surfing the Tsunami Wave. Open Praxis, 8(3), 203-221. https://doi.org/10.5944/openpraxis.8.3.287

Bonafini, F. C., Chae, C., Park, E., \& Jablokow, K. W. (2017). How much does student engagement with videos and forums in a MOOC affect their achievement? Online Learning Journal, 21(4), 223240. https://doi.org/10.24059/olj.v21i4.1270

Cabero Almenara, J., \& López Meneses, E. (2009). Descripción de un instrumento didactico para el analisis de modelos y estrategias de enseñanza de cursos universitarios en la red (A.D.E.C.U.R.). [Description of a didactic instrument for the analysis of models and strategies for teaching university courses in the network (A.D.E.C.U.R.)]. Píxel-Bit. Revista de Medios y Educación, 34, 13-30.

Cabero-Almenara, J., Marín-Díaz, V., \& Sampedro-Requena, B. E. (2017). Research contributions on the educational use of MOOCs. Revista Espanola de Pedagogia, 75(266), 7-27. https://doi.org/10.22550/REP75-1-2017-01

Campbell, J., Gibbs, A., Najafi, H., \& Severinski, C. (2014). A comparison of learner intent and behaviour in live and archived MOOCs. International Review of Research in Open and Distance Learning, 15(5), 235-262.

Castaño, C., Maíz, I., \& Garay, U. (2015). Design, motivation and performance in a cooperative MOOC course. Comunicar, 44, 19-26.

Chapman, S. A., Goodman, S., Jawitz, J., \& Deacon, A. (2016). A strategy for monitoring and evaluating massive open online courses. Evaluation and Program Planning, 57, 55-63.

Chiappe-Laverde, A., Hine, N., \& Martínez-Silva, J.-A. (2015). Literature and practice: A critical review of moocs. Comunicar, 22(44), 9-18. https://doi.org/10.3916/C44-2015-01

Chen, J., Xu, W., Xu, H., Peng, W., \& Xing, B. (2017). Research on vocational tendency and learning quality. Revista de la Facultad de Ingenieria, 32(6), 257-262.

Chiou, Y., \& Shih, T. K. (2015). Auto grouping and peer grading system in massive open online course (MOOC). International Journal of Distance Education Technologies, 13(3), 25-43. https://doi.org/10.4018/IJDET.2015070102

Christoforaki, M., \& Ipeirotis, P. G. (2015). A system for scalable and reliable technical-skill testing in online labor markets. Computer Networks, 90, 110-120. https://doi.org/10.1016/j.comnet.2015.05.020

Cormier, D., \& Siemens, G. (2010). Through the Open Door: Open Courses as Research, Learning, and Engagement. EDUCAUSE Review, 45(4), 31-39. 
Coursera. (March, 2017). Introducing Our New Infographic: How the World Learns. Retrieved March 24,2017 from http://coursera.tumblr.com/post/142363925112/introducing-our-newinfographic-how-the-world

Duart, J. M., Roig-Vila, R., Mengual-Andrés, S., \& Maseda, D. (2017). The pedagogical quality of MOOCs based on a systematic review of JCR and Scopus publications (2013-2015). Revista Española de Pedagogía, 75(266), 29-46.

El Ahrache, S. I., Hassan, B., Tabaa, Y., \& Medouri, A. (2013). Massive Open Online Courses: A New Dawn for Higher Education? International Journal on Computer Science and Engineering (IJCSE), 5, 323-327.

Eranki, K. L. N., \& Moudgalya, K. M. (2016). Comparing the Effectiveness of Self-Learning Java Workshops with Traditional Classrooms. Educational Technology \& Society, 19(4), 59-74.

Estévez-Ayres, I., Crespo-García, R. M., Fisteus, J. A., \& Kloos, C. D. (2013). An algorithm for peer review matching in Massive courses for minimising students' frustration. Journal of Universal Computer Science, 19(15), 2173-2197.

Farhan, M., \& Aslam, M. (2017). An Interactive Assessment Framework for Visual Engagement: Statistical Analysis of a TEDx Video. Eurasia Journal of Mathematics, Science and Technology Education, 13(4), 1107-1119. https://doi.org/10.12973/eurasia.2017.00661a

Frick, T., \& Dagli, C. (2016). MOOCs for Research: The Case of the Indiana University Plagiarism Tutorials and Tests. Technology, Knowledge and Learning, 21(2), 255-276.

D. Gamage, S. Fernando and I. Perera, "Quality of MOOCs: A review of literature on effectiveness and quality aspects," 2015 8th International Conference on Ubi-Media Computing (UMEDIA), Colombo, 2015, (pp. 224-229).

Ghislandi, P. (2016). "The fun they had" or about the quality of MOOC. Journal of E-Learning and Knowledge Society, 12(3), 99-114.

Gisbert, J. y Bonfill, X. (2004). How to perform, evaluate and use systematic reviews and meta-analyzes? [¿Cómo realizar, evaluar y utilizar revisiones sistematicas y metaanalisis?] Gastroenterología y Hepatología, 27(3), 129-149.

Goldberg, L. R., Bell, E., King, C., O’Mara, C., McInerney, F., Robinson, A., \& Vickers, J. (2015). Relationship between participants' level of education and engagement in their completion of the Understanding Dementia Massive Open Online Course Approaches to teaching and learning. BMC Medical Education, 15(1). https://doi.org/10.1186/s12909-015-0344-z

Gómez Hernandez, P., Monge López, C., \& Sebastian Heredero, E. (2016). Quality of a mooc inclusion on education: implementation of various instruments and indicators [Calidad de un MOOC sobre inclusión educativa: Aplicación de varios instrumentos e indicadores]. Revista IberoAmericana de Estudos em Educação, 11(25).

Grant, M. J. y Booth, A. (2009). A typology of reviews: an analysis of 14 review types and associated methodologies. Health Information and Libraries Journal, 26(2), 91-108.

Gray, C. (2015). Exploring measures of engagement in open online work based learning: Towards better measures of success in open online learning methods, massive or otherwise. International Journal of Technologies in Learning, 22(3), 41-50.

Greene, J. A., Oswald, C. A., \& Pomerantz, J. (2015). Predictors of Retention and Achievement in a Massive Open Online Course. American Educational Research Journal, 52(5), 925-955. 
Hills, L., \& Hughes, J. (2016). Assessment worlds colliding? Negotiating between discourses of assessment on an online open course. Open Learning, 31(2), 108-115.

https://doi.org/10.1080/02680513.2016.1194747

Hsieh, M.-Y. (2016). Online learning era: Exploring the most decisive determinants of MOOCs in Taiwanese higher education. Eurasia Journal of Mathematics, Science and Technology Education, 12(5), 1163-1188. https://doi.org/10.12973/eurasia.2016.1504a

Inventado, P. S., \& Scupelli, P. (2017). An online learning collaboratory to address multidisciplinary learning challenges at scale. Interaction Design and Architecture(s), (33), 11-32.

Isaksson, R., Garvare, R., Johnson, M., Kuttainen, C., \& Pareigis, J. (2015). Sustaining Sweden’s competitive position: lean lifelong learning. Measuring Business Excellence, 19(1), 92-102.

Kahan, T., Soffer, T., \& Nachmias, R. (2017). Types of participant behavior in a massive open online course. International Review of Research in Open and Distance Learning, 18(6), 1-18. https://doi.org/10.19173/irrodl.v18i6.3087

Khalil, M., Brunner, H., \& Ebner, M. (2015). Evaluation Grid for xMOOCs. International Journal of Emerging Technologies in Learning, 10(4), 40-45.

Kitchenham, B. A. y Charters, S. (2007). Guidelines for performing Systematic Literature Reviews in Software Engineering. Version 2.3 (EBSE-2007-01).

Law, P. (2015). Recognising informal elearning with digital badging: evidence for a sustainable business model. Open Praxis, 7(4), 299-310.

Leach, M., \& Hadi, S. M. (2017). Supporting, categorising and visualising diverse learner behaviour on MOOCs with modular design and micro-learning. Journal of Computing in Higher Education, 29(1), 147-159. https://doi.org/10.1007/s12528-016-9129-6

Leony, D., Muñoz-Merino, P. J., Ruipérez-Valiente, J. A., Pardo, A., \& Kloos, C. D. (2015). Detection and evaluation of emotions in massive open online courses. Journal of Universal Computer Science, 21(5), 638-655.

Liu, Z., Liu, S., Liu, L., Sun, J., Peng, X., \& Wang, T. (2016). Sentiment recognition of online course reviews using multi-swarm optimization-based selected features. Neurocomputing, 185, 11-20. https://doi.org/10.1016/j.neucom.2015.12.036

Liyanagunawardena, T. R., Adams, A. A., \& Williams, S. A. (2013). MOOCs: A systematic study of the published literature 2008-2012. International Review of Research in Open and Distance Learning, 14(3), 202-227.

Loftis, E., \& Martínez Wormser, J. (2016). Developing online information literacy instruction for the undergraduate art student: a collaborative approach in the context of the framework for information literacy. Art Documentation, 35(2), 241-261.

MacKay, J. R. D., Langford, F., \& Waran, N. (2016). Massive open online courses as a tool for global animal welfare education. Journal of Veterinary Medical Education, 43(3), 287-301.

Masanet, E., Chang, Y., Yao, Y., Briam, R., \& Huang, R. (2014). Reflections on a massive open online life cycle assessment course. The International Journal of Life Cycle Assessment, 19(12), 19011907.

Margaryan, A., Bianco, M., \& Littlejohn, A. (2015). Instructional quality of Massive Open Online Courses (MOOCs). Computers \& Education, 80, 77-83. https://doi.org/10.1016/j.compedu.2014.08.005 
Meek, S. E. M., Blakemore, L., \& Marks, L. (2017). Is peer review an appropriate form of assessment in a MOOC? Student participation and performance in formative peer review. Assessment and Evaluation in Higher Education, 42(6), 1000-1013. https://doi.org/10.1080/02602938.2016.1221052

Mengual-Andrés, S., Lloret Catala, C., \& Roig Vila, R. (2015). Validation of the Questionnaire of Quality Assessment of Online Courses adapted to MOOC [Validación del Cuestionario de evaluación de la calidad de cursos virtuales adaptado a MOOC]. Ried-Revista Iberoamericana De Educación a Distancia, 18(2), 145-169.

Montero, I., \& León, O. G. (2007). A guide for naming research studies in Psychology. International Journal of Clinical and Health Psychology, 7(3), 847-862.

Moskal, P., Thompson, K., \& Futch, L. (2015). Enrollment, engagement, and satisfaction in the BlendKit faculty development open, online course. Journal of Asynchronous Learning Network, 19(4).

Muñoz-Merino, P. J., Ruipérez-Valiente, J. A., Delgado, K., Auger, M. A., Briz, S., de, C., \& Santalla, S. N. (2017). Flipping the classroom to improve learning with MOOCs technology. Computer Applications in Engineering Education, 25(1), 15-25. https://doi.org/10.1002/cae.21774

Patru, M., \& Balaji, V. (Eds.). (2016). Making sense of MOOCs, A Guide for Policy-Makers in Developing Countries. París: Unesco: Commonwealth of Learning. Retrieved from http://unesdoc.unesco.org/images/0024/002451/245122E.pdf

Petersen, K., Feldt, R., Mujtaba, S. \& Mattsson, M. (2008). Systematic Mapping Studies in Software Engineering. EASE, 8, 68-77.

Roig-Vila, R., Mengual Andrés, S., \& Suarez Guerrero, C. (2014). Assessment the pedagogical quality of the MOOC [Evaluación de la calidad pedagógica de los MOOC]. El Profesorado, 18(1), 27-41.

Ruipérez-Valiente, J. A., Muñoz-Merino, P. J., Pijeira, D., Ruiz, J. S., \& Kloos, C. D. (2017). Evaluation of a learning analytics application for open edX platform. Computer Science and Information Systems, 14(1), 51-73. https://doi.org/10.2298/CSIS160331043R

Ruiz Bras, I. I. (2016). Mooc in numbers, an analysis to begin reflection [Los MOOC en números, un analisis para comenzar la reflexión]. Revista Digital Universitaria, 17(1), 1-16.

Russell, E. J. (2012). The role of servant leadership in faculty development programs: A review of the literature. Turkish Online Journal of Distance Education, 13(1), 15-19.

Sa'Don, N. F., Alias, R. A., \& Ohshima, N. (2015). Nascent research trends in MOOCs in higher educational institutions: A systematic literature review. Presentado en 2014 International Conference on Web and Open Access to Learning, ICWOAL 2014. https://doi.org/10.1109/ICWOAL.2014.7009215

Sinclair, J., \& Kalvala, S. (2016). Student engagement in massive open online courses. International Journal of Learning Technology, 11(3), 218-237. https://doi.org/10.1504/IJLT.2016.079035

Sinclair, J., Boyatt, R., Foss, J., \& Rocks, C. (2016). A study of user participation across different delivery modes of a massive open online course. International Journal of Learning Technology, 11(2), 93-113.

Smith, M. A. (2015). Output from statistical predictive models as input to elearning dashboards. Future Internet, 7(2), 170-183. https://doi.org/10.3390/fi7020170

Tiejun, Z. (2016). Empirical research on the effectiveness of MOOCs in developing design students on sino-foreign cooperation university programs. International Journal of Emerging Technologies in Learning, 11(6), 19-27. 
Torres-Coronas, T., \& Vidal-Blasco, M.-A. (2017). MOOC and blended learning models: Analysis from a stakeholders' perspective. International Journal of Information and Communication Technology Education, 13(3), 88-99. https://doi.org/10.4018/IJICTE.2017070107

UNESCO (March, 2017). La UNESCO lanza una guía de cursos por Internet de libre acceso para los países en desarrollo [UNESCO launches a free online course guide for developing countries]. Retrieved 24 March from http://www.unesco.org/new/es/media-services/singleview/news/unesco_launch_for_massive_open_online_courses_guide_for_deve/

Veletsianos, G., \& Shepherdson, P. (2016). A systematic analysis and synthesis of the empirical MOOC literature published in 2013-2015. International Review of Research in Open and Distance Learning, 17(2), 198-221.

Wittek, L., \& Kvernbekk, T. (2011). On the Problems of Asking for a Definition of Quality in Education. Scandinavian Journal of Educational Research, 55(6), 671-684.

Yepes-Baldó, M., Romeo, M., Martín, C., García, M. A., Monzó, G., \& Besolí, A. (2016). Quality indicators: developing "MOOCs" in the European Higher Education Area. Educational Media International, 53(3), 184-197.

Yousef, A. M. F., Chatti, M. A., Schroeder, U., Wosnitza, M., \& Jakobs, H. (2014). MOOCs a review of the state-of-the-art (Vol. 3, pp. 9-20). Presentado en CSEDU 2014 - Proceedings of the 6th International Conference on Computer Supported Education.

Yousef, A., Chatti, M., Schroeder, U., \& Wosnitza, M. (2015). A usability evaluation of a blended MOOC environment: An experimental case study. International Review of Research in Open and Distance Learning, 16(2), 69-93.

Zawacki-Richter, O., Bozkurt, A., Alturki, U., \& Aldraiweesh, A. (2018). What research says about MOOCs - An explorative content analysis. International Review of Research in Open and Distance Learning, 19(1), 242-259. https://doi.org/10.19173/irrodl.v19i1.3356

Zhu, M., Sari, A., \& Lee, M. M. (2018). A systematic review of research methods and topics of the empirical MOOC literature (2014-2016). Internet and Higher Education, 37, 31-39. https://doi.org/10.1016/j.iheduc.2018.01.002 